\title{
The Effect of Ease of Transaction and Service Quality on Purchasing Decisions Mediated by Consumer Satisfaction (Studies on Okeped Jabodetabek Users).
}

\author{
Melitina Tecoalu ${ }^{1}$ ) \\ melitina@ukrida.ac.id \\ Soegeng Wahyoedi ${ }^{2}$ ) \\ swahyoedi@ukrida.ac.id \\ Edward Kustiawan *3) \\ Krida Wacana Christian University, Jakarta \\ *) Coressponding Author: edward.2018mm084@civitas.ukrida.ac.id
}

\begin{abstract}
This study aims to determine the effect of ease of transaction and service quality on customer satisfaction in purchasing decision making. In this study using a sample of 100 respondents using convience sampling non profitability. Data obtained through questionnaires, the data collection process in this study is Structural Equation Modeling (SEM) with the SmartPLS (Partial Least Square) 3.0 program to determine the relationship between the effect of Ease of Transaction, Service Quality on Purchasing Decisions and Consumer Satisfaction as a mediating variable.

The results of the hypothesis that there are 4 accepted and 3 rejected after being tested by hypothesis testing is done using the probability value and the $t$ statistic. So in the hypothesis acceptance criteria t-statistic $>\mathrm{t}$-table. Ease of transaction affects customer satisfaction, so the hypothesis is accepted. Service quality affects customer satisfaction, so the hypothesis is accepted. Ease of transaction affects purchasing decisions, so the hypothesis is accepted. Service quality affects purchasing decisions, so the hypothesis is accepted. Consumer satisfaction has no effect on purchasing decisions, so the hypothesis is rejected. The service quality on purchasing decisions is not mediated by consumer satisfaction well so that the hypothesis is rejected. Ease of transaction on purchasing decisions is not mediated in consumer satisfaction well, so the hypothesis is rejected. In this study, it is explained that the purchasing decision is not well mediated by consumer satisfaction so that consumers who do not reach their expectations feel dissatisfied, which leads to not making purchasing decisions on Okeped.
\end{abstract}

Keyword:ease of transactions; service quality; customer satisfaction; purchasing decision; SmartPLS. 


\section{PRELIMINARY}

In the beginning of technological development until now, which is very fast, has a connection with encouraging internet development activities. In its development, the internet itself has an electronic media that supports the occurrence of ecommerce (electronic commerce), this has the impact of rapid growth. The application of e-commerce is where the process of facilitating a buying and selling activity is only done online, the speed with which the times are happening has made the existing internet speed as it is today, in Indonesia getting internet speeds up to $4 \mathrm{G}$ in other countries has entered the 5G internet speed technology, all needs are made easier in an efficient, fast, cheap and easier way. Indonesia is a developing country that has a significant growth rate of internet users every year, this can also be proven by using projection data on the number of Internet users according to the Indonesian Internet Service Providers Association (APJII) :

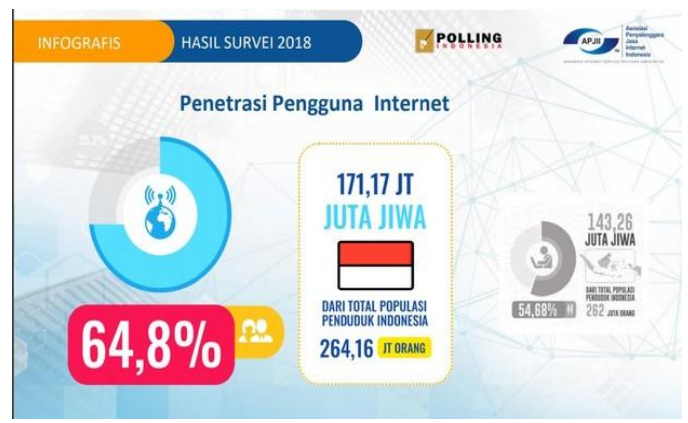

recorded 171.17 million Internet users 2018 from the total population of Indonesia 264.14 million which can be said to be $64.8 \%$, the use of the Internet will increase every year, from this data it can be said that this is an opportunity that can still be achieved in developing a marketplace business. There are many companies that want to create an online or e-commerce site that is able to provide the best of all its features so that it can be of interest and use, when developing and creating the site it must be easy, safe, high quality, and can be trusted by consumers later so that with this, it is hoped that it will be able to provide value for its products, be more efficient, and cheaper. Ease of transaction that are having an understanding where something must be issued or made sacrifices from consumers in order to get efficient, relatively easy, efficient, and comfortable service or get quality products (Irawan, 2009). The ease of transactions itself will make potential customers feel comfortable in seeing all its features from the initial account creation, data verification, when looking for goods, the process of entering goods, selecting logistics, assistance services when encountering problems can be resolved quickly, thus making transactions easier This is an advantage over other ecommerce and makes people want to use it even from that they want to refer to relatives, family, friends and the surrounding environment when they want to carry out online trading . Service quality according to Irawan (2009) is the result of consumer assessment when using products and services, and has a driving factor for satisfaction : 1) service quality ,2) product quality, 3) cost and convenience, 4) emotional factors and 5) price. These driving factors are the key to the service quality that will be provided to potential consumers by providing answers to consumer questions with everything 
needed according to the expectations of these answers, providing filter features for the most recommended product quality, shops, reviews, how many The large number of product transactions that are open in general will give confidence in the products to be purchased on the selected marketplace .

In the emotional factor itself, it can occur in the choice of e-commerce that consumers will choose, how marketplace companies compete in branding their companies into e-commerce companies used by many consumers because very complete facilities are provided by potential consumers and shape comfort by features -Features as an advantage that make this emotional factor work in the service quality so that consumers choose because of the service quality that already has a name and many recommend the use of this e-commerce. In transparent pricing, it is easy to check products and carry out transactions in the buying process or problems that occur. Service quality is the most important thing in e-commerce voters who will stop by until the transaction by consumers occurs, in Miramadi and Nawaser's research (2011) it provides an understanding that service quality is the most important component in increasing satisfaction. When getting service quality according to expectations, consumers do not hesitate to provide recommendations to those around them. When performance exceeds expectations, consumers are very satisfied or happy (Kotler 2016), so that satisfaction is an impression of the performance that has occurred and the expectations imagined. The satisfaction that will be received by consumers can be measured without having to spend, by getting convenience in the transaction, by the many types of products provided, they can transparently see the products that have been sold, have a good review, the types of delivery logistics services are very much and Consumers can choose from those provided, types of payments that make it very easy to use from debit, credit, virtual accounts, offline store services at Alfamart, Indomaret, e-wallet (OVO), fintech payments from which satisfaction will be achieved by consumers so that confidence will emerge when you want to make a purchase. In a purchasing decision, it can occur when a product or service selection is realized by consumers making the choices they buy and use, according to Kotler and Amstrong (2018) that the behavior of consumer purchasing decisions refers to the consumer's final purchase behavior, either individually, or for household needs that buy goods or services for personal consumption. Meanwhile, according to Swastha (2008) the purchasing decision has an understanding of the approach based on solving problems in an activity carried out by humans to buy goods or services in fulfilling their wants and needs, which consists of the introduction of needs and desires, information search, evaluation of purchase alternatives, purchaing decisions, and post-purchase behavior. From the theory above, it can be concluded that the purchasing decision itself is a physical and real decision from several alternative choices and choosing one of them to be carried out to buy a product or service to be seen and measured by others. The Okeped company is one of the companies that has a business model for an online buying and selling site or a marketplace that has become a Unicorn, and one company that is able to successfully enter into an industry that can absorb MSMEs, where Okeped allows to provide equal opportunities for sellers, buyers, wellknown brands, and offline micro, small and medium enterprises (MSMEs ) can make and also have online sales on the Okeped marketplace . This study aims to examine the effect of ease of transaction and service 
quality, customer satisfaction, purchasing decision. This study also intends to examine the mediation of consumer satisfaction on the effect of ease of transaction and service quality on purchasing decisions. The results of this study are expected to be a reference material as well as a comparison of research on e-commerce service companies in the marketplace, related to ease of transactions and service quality to consumer satisfaction in purchasing decisions.

\section{LITERATURE REVIEW}

\section{Ease of Transaction}

Ease of transaction is a consideration for someone to shop, the more convenience it is given, the more loyal consumers use it. A system that is difficult to use will be avoided by consumers Celik and Yilmaz, (2011) . The effect of the ease of transactions by users which has a system connection with the buying and selling process that will occur online. Most of the customers who are going to shop see it from the initial appearance that it is easy, and it is interesting to shop at that place because of the ease of the transaction, where the ease is also related to the security of the transaction that occurs, where potential users are still unfamiliar with buying and selling online. As on the other hand there are users who are trying to want to try the way of seeking more information about how the transaction in the marketplace selling sites online. In marketplace, which provides online sales services, it provides reliable performance where the users are used and also in the process of the entire transaction process, as well as guarantees the ease of searching, payment and security of the transaction.

\section{Service Quality}

Service quality is a level where the good or bad of these activities can be defined separately, which in essence has an intangible character, it is a fulfillment of needs. Providing a service is very closely related to giving satisfaction to every customer who transacts, service by providing good quality quality can provide positive satisfaction for its consumers, so that consumers will be able to feel more attention to its existence by the seller. In terms of service quality itself has a picture as a complement that needs to be realized by the seller because it has the influence to be able to bring in new customers and can also reduce the possibility of old consumers to switch to other sellers. According to Yulianto (2010), service quality is a service that we provide to consumers. Quality is also an overall characteristic of a product and service that can provide satisfaction to its users (Prasetio, 2012). The higher the level of service quality leads to higher customer satisfaction and also supports higher prices and lower costs. Service quality is described as a combination of service attributes or dimensions that consumers want (Yuen \& Thai, 2015).

\section{Consumer Satisfaction}


According to Supranto, (2011) satisfaction is the level of a person's feelings after comparing perceived performance / results with expectations, so the level of satisfaction is a function of the difference between perceived performance and expectations. If it is not in accordance with consumer expectations, it will cause disappointment for these consumers, where as if it is in accordance with consumer expectations or can even exceed expectations, it will lead to satisfaction and very satisfied for these consumers . According in Kotler (2016), consumer satisfaction variables can be measured using 3 indicator items,: repurchase (re-purchase), word-of-mouth (word of mouth), and creating purchasing decisions at company $e$-commerce the same, and according to Schiffman and Kanuk (2010) consumer behavior is as follows. "The term consumer behavior is defined as the behavior that consumers pay attention to in finding, buying, using, evaluating and spending the products and services they hope to satisfy their needs". Meanwhile, Engel, Blackwell and Miniard (1993) in Sumarwan (2011) define it as actions that are directly involved in obtaining, consuming, and consuming products or services, including the decision process that precedes and follows these actions.

\section{Purchase decision}

The purchasing decision process according to Kotler (2016) states that the decision to buy made by the buyer is actually a collection of a number of decisions. Each decision to purchase has a structure of seven components consisting of : decisions about the type of product, decisions about the shape of the product, brand, sales, number of products, time of purchase, and method of payment. Schiffman and Kanuk (2010) state that a decision is to have a selection in two or more alternative options, so that it can be stated that there are alternative choices when making decisions. In a decision without other options is not a decision on a situation without choice is usually called "Hobson's choice ". According to Kotler and Amstrong (2018) revealed that: "purchasing decisions are solving activities carried out by individuals in selecting suitable alternatives from two or more alternatives and are considered as the most appropriate action in buying by first going through the process stages. decision-making". From the explanation above it can be explained that the purchasing decision is made after making a comparison of two or more in determining a product to be purchased, the consumer considers the quality of services provided and also includes competitive prices, and the ease of transactions which also includes features. security, which allows people to conclude to buy at these options.

\section{RESEARCH METHODS}

In this study the authors used the nonprobability method, according to Sugiyono (2018) having an understanding of techniques in sampling that did not provide equal opportunity or opportunity in selecting elements and populations in the selection of a sample. The techniques are systematic sampling, quotas, accidentl sampling, purposive, saturation and snowball. This research will use accidental sampling technique, which in its understanding was found by chance and has a match as a sample from data sources in the Jabodetabek area that has used Okeped with a sample of 100 people. The data analysis technique of this research uses Structural Equation Modeling (SEM ), SEM - PLS is a method that is widely used in eliminating weaknesses 
in the regression method. According to Ghozali (2015) SEM is an evolution of a multiple equation model developed from econometric principles and combined with regulatory principles from psychology and sociology, SEM has emerged as an integral part of academic managerial research. SEM techniques have been used by many researches in different fields, such as economics, education, marketing biology, health and various other branches of science. The PLS itself uses the outer model and inner model data analysis. The outer model is the Discriminant Validity Test, Cross Loading, Avarage Variance Extracted (AVE), Composite Realibility, and Cronbach's alpha. Inner model test is $\mathrm{R}$ square, Q square and, Estimate for Path Coefficient (Direct and Indirect), which is the value of the path coefficient or the magnitude of the relationship or effect of latent constructs using the Bootstrapping procedure.

\section{RESULTS AND DISCUSSION}

For all the variables in this study, which include ease of transactions, service quality, customer satisfaction and purchasing decisions by examining the use of outer loading as expected $>0.40$ and it is considered that the loading value $>0.70$ is considered significant. In this validity test, it must be done at the beginning to be able to measure the validity level of all existing variables. It can be seen the validity test of the ease of transactionvariable $0.827 ; 0.906 ; 0.880 ; 0.811 ; 0.789$; variable servicequality $0.866 ; 0.850 ; 0$ $.811 ; 0.777 ; 0.693$,variable customersatisfaction $0.808 ; 0.853 ; 0.817 ; 0.779 ; 0.597 ;$ and purch asedecision variable $0.833 ; 0.741 ; 0.888 ; 0.849$. The following table from the test:

Table 4.1

Outer Loading

\begin{tabular}{|c|c|c|}
\hline Variable & Indicator & Outer Loading \\
\hline \multirow{5}{*}{ Ease Of Transaction } & KT1 & 0.827 \\
\hline & KT2 & 0.906 \\
\hline & KT3 & 0.880 \\
\hline & KT4 & 0.811 \\
\hline & KT5 & 0.789 \\
\hline \multirow{5}{*}{ Service Quality } & KL1 & 0.866 \\
\hline & KL2 & 0.850 \\
\hline & KL3 & 0.811 \\
\hline & KL4 & 0.777 \\
\hline & KL5 & 0.693 \\
\hline \multirow{5}{*}{ Customer Satisfaction } & KK1 & 0.808 \\
\hline & KK2 & 0.853 \\
\hline & KK3 & 0.817 \\
\hline & KK4 & 0.779 \\
\hline & KK5 & 0.597 \\
\hline \multirow[t]{4}{*}{ Purchasing Decision } & KP1 & 0.833 \\
\hline & KP2 & 0.741 \\
\hline & KP3 & 0.888 \\
\hline & KP4 & 0.849 \\
\hline
\end{tabular}


Based on these results, it can be concluded that all existing variable indicators meet the valid requirements because $>0.40$, it can be concluded that the appropriate measuring instrument for the variables of ease of transactions, service quality, customer satisfaction and purchasing decision.

Table 4.2

Discriminant Validity

\begin{tabular}{|c|c|c|c|c|}
\hline & KK & KL & KP & KT \\
\hline KK & 0.776 & & & \\
\hline KL & 0.820 & 0.802 & & \\
\hline KP & 0.710 & 0.733 & 0.830 & \\
\hline KT & 0.643 & 0.660 & 0.744 & 0.844 \\
\hline
\end{tabular}

Source: Results of SMARTPLS Data Processing, 2021

In discriminant validity using the Fornell-Larcker criterion, which is used to convince the discriminant, then the AVE for each latent variable must be higher than $\mathrm{R}^{2}$ with all other latent variables. Thus, each latent variable shares a variant with its indicator block rather than with other latent variables representing a different block of indicator blocks.

Table 4.3

Cross Loading

\begin{tabular}{|c|c|c|c|c|}
\hline & KK & KL & KP & KT \\
\hline KK1 & 0.808 & 0.674 & 0.528 & 0.442 \\
\hline KK2 & 0.853 & 0.696 & 0.517 & 0.494 \\
\hline KK3 & 0.817 & 0.569 & 0.515 & 0.452 \\
\hline KK4 & 0.779 & 0.758 & 0.648 & 0.569 \\
\hline KK5 & 0.597 & 0.420 & 0.525 & 0.532 \\
\hline KL1 & 0.667 & 0.866 & 0.682 & 0.652 \\
\hline KL2 & 0.659 & 0.850 & 0.644 & 0.591 \\
\hline KL3 & 0.636 & 0.811 & 0.565 & 0.477 \\
\hline KL4 & 0.634 & 0.777 & 0.572 & 0.568 \\
\hline KL5 & 0.692 & 0.693 & 0.458 & 0.333 \\
\hline KP1 & 0.552 & 0.528 & 0.833 & 0.614 \\
\hline KP2 & 0.598 & 0.556 & 0.741 & 0.533 \\
\hline KP3 & 0.647 & 0.711 & 0.888 & 0.658 \\
\hline KP4 & 0.557 & 0.623 & 0.849 & 0.656 \\
\hline KT1 & 0.578 & 0.544 & 0.704 & 0.827 \\
\hline KT2 & 0.630 & 0.635 & 0.686 & 0.906 \\
\hline KT3 & 0.543 & 0.633 & 0.661 & 0.880 \\
\hline KT4 & 0.481 & 0.467 & 0.496 & 0.811 \\
\hline KT5 & 0.455 & 0.479 & 0.556 & 0.789 \\
\hline
\end{tabular}


Source: Results of SMARTPLS Data Processing, 2021

In this section we will describe the results of the discriminant validity test. The discriminant validity test using cross-loading is used to check the validity of the discriminants in addition to the Fornell-Larcker criteria. An indicator is declared to meet discriminant validity if the cross loading of the indicator on the variable is the largest compared to other variables. Based on the data in table 4.2 above, it can be seen that the value of each variable indicator in the research variable is the largest crossloading value on the variable it forms compared to the cross-loading value on other variables, from the results obtained it can be stated that the indicators used in this study, it has good discriminant validity in compiling each of the variables.

Table 4.4

Avarage Variane Extracted (AVE)

\begin{tabular}{|c|c|}
\hline Variable & AVE \\
\hline Ease Of Transaction (X1) & 0.712 \\
\hline Service Quality (X2) & 0.643 \\
\hline Customer Satisfaction $(\mathrm{Z})$ & 0.602 \\
\hline Purchasing Decision $(\mathrm{Y})$ & 0.688 \\
\hline
\end{tabular}

Source: Results of SMARTPLS Data Processing, 2021

From table 4.4, the results of the Avarage Varians Extracted (AVE) value on the variables in accordance with the provisions $>0.5$. By paying attention to the values in table 4.1 outer loading, 4.2 discriminant validty, 4.3 cross-loading and the results of Avarage Varians Extracted (AVE) in table 4.4, so that the results of the study are in accordance with applicable regulations. The test results above state that the indicators used represent the variables used.

Table 4.5

Composite Reliability

\begin{tabular}{|c|c|}
\hline Variable & Composite Reability \\
\hline Ease of transaction $(\mathrm{X} 1)$ & 0.925 \\
\hline Service quality $(\mathrm{X} 2)$ & 0.899 \\
\hline Customer Satisfaction $(\mathrm{Z})$ & 0.882 \\
\hline Purchasing Decision $(\mathrm{Y})$ & 0.898 \\
\hline
\end{tabular}

Source: Results of SMARTPLS Data Processing, 2021

Based on the composite reliability of the management data, that the variables in this research reliable because it has a value of composite reliability $>0,7$.

Table 4.6

Cronbach's Alpha 


\begin{tabular}{|c|c|}
\hline Variable & Cronbach's Alpha \\
\hline Ease Of Transaction (X1) & 0.899 \\
\hline Service Quality (X2) & 0.859 \\
\hline Customer Satisfaction (Z) & 0.831 \\
\hline Purchasing Decision (Y) & 0.847 \\
\hline
\end{tabular}

Source: Results of SMARTPLS Data Processing, 2021

In the table above, the results from table 4.5 of composite reliability can be strengthened by looking at the value from table 4.6 Cronbach's alpha. That each variable has a value> 0,7 , so that all variables in this study are said to be reliable. From the results will be that the existing indicators in this study can be declared reliable to represent each variable. The inner model test is a way to see the relationship between latent variables through the bootsrapping method .

In the inner model analysis can be done in 2 ways, by R-square and Qsquare. Evaluation of the test using R-sq u re as the dependent construct, Stone- Geiser with Q-squar e test for the relevant predictive. In the R-square value is used to measure the value of certain independent latent variables on the dependent latent variable. The higher the R-square value then it will be greater the ability of independent latent variables can menjeleaskan dependent latent variables. According to Ghozali, 2015, the R-square results are 0.67 (good), 0.33 (moderate), and 0.19 (weak).

Table 4.7

R-square

\begin{tabular}{|c|c|}
\hline Variable & R- Square \\
\hline Customer Satisfaction $(\mathrm{Z})$ & 0.690 \\
\hline Purchasing Decision $(\mathrm{Y})$ & 0.670 \\
\hline
\end{tabular}

Source: Results of SMARTPLS Data Processing, 2021

In the inner model analysis, the value of the Q-square can also be calculated, using the calculation formula as follows:

$$
\begin{aligned}
\text { Q-square = } 1 & -\left(1-R^{2}\right) \times\left(1-R^{2}\right) \\
& =1-(1-0.690) \times(1-0.670) \\
& =1-(0.31 \times 0.33) \\
& =1-0.102 \\
& =0.898
\end{aligned}
$$

According to the results of the Q-square calculation, it has a result of 0.898 , which can be explained that the magnitude of the various results from the existing data from this study is $89.8 \%$, and $10.2 \%$ is explained by other factors outside of this study.

Table 4.8 


\begin{tabular}{|l|c|l|c|c|c|}
\hline & $\begin{array}{l}\text { Original } \\
\text { Sample (O) }\end{array}$ & $\begin{array}{l}\text { Sample } \\
\text { Mean (M } \\
\text { ) }\end{array}$ & $\begin{array}{l}\text { Standard } \\
\text { Deviation }\end{array}$ & $\begin{array}{l}\text { t- Statistics ( O / V Values } \\
\text { STERR /) }\end{array}$ & | \\
\hline KL> KK> KP & 0.140 & 0.137 & 0.100 & 1,399 & 0.162 \\
\hline KT> KK> KP & 0.036 & 0.032 & 0.057 & 1,142 & 0.254 \\
\hline
\end{tabular}

Source : Smart PLS Data Management Results , 2021

From the results of the Specific Indirect Effect table in Table 4.8, it is known that from 2 mediation effects, each mediated variable is declared to have no significant effect and the hypothesis is declared neither accepted nor rejected because the t-statistic is $<1.96$ and has a P-value of $>0,05$. In managing data, ease of transaction and service quality has an influence on purchasing decisions, but customer satisfaction cannot mediate well on purchasing decisions, this can be seen from the results of table 4.8 which has a tstatistic of 1.399 and 1.142 and a P-value of 0.162 and 0.254 which states that service quality and ease of transactions are not well mediated bycustomer satisfaction with purchasing decisions. In the SmartPLS system, testing of each relationship is carried out using a simulation with the bootstrapping method of the sample. In this test, it aims to be able to minimize problems in the abnormalities in the study. Following are the test results with the bootsrapping method from SmartPLS, which are as follows:

\section{Figure 4.8 Bootstrapping Model}

Source: SmartPLS Data Processing Results (2021)

To test the hypothesis used to test whether the hypothesis formed at the beginning of the study is significant.

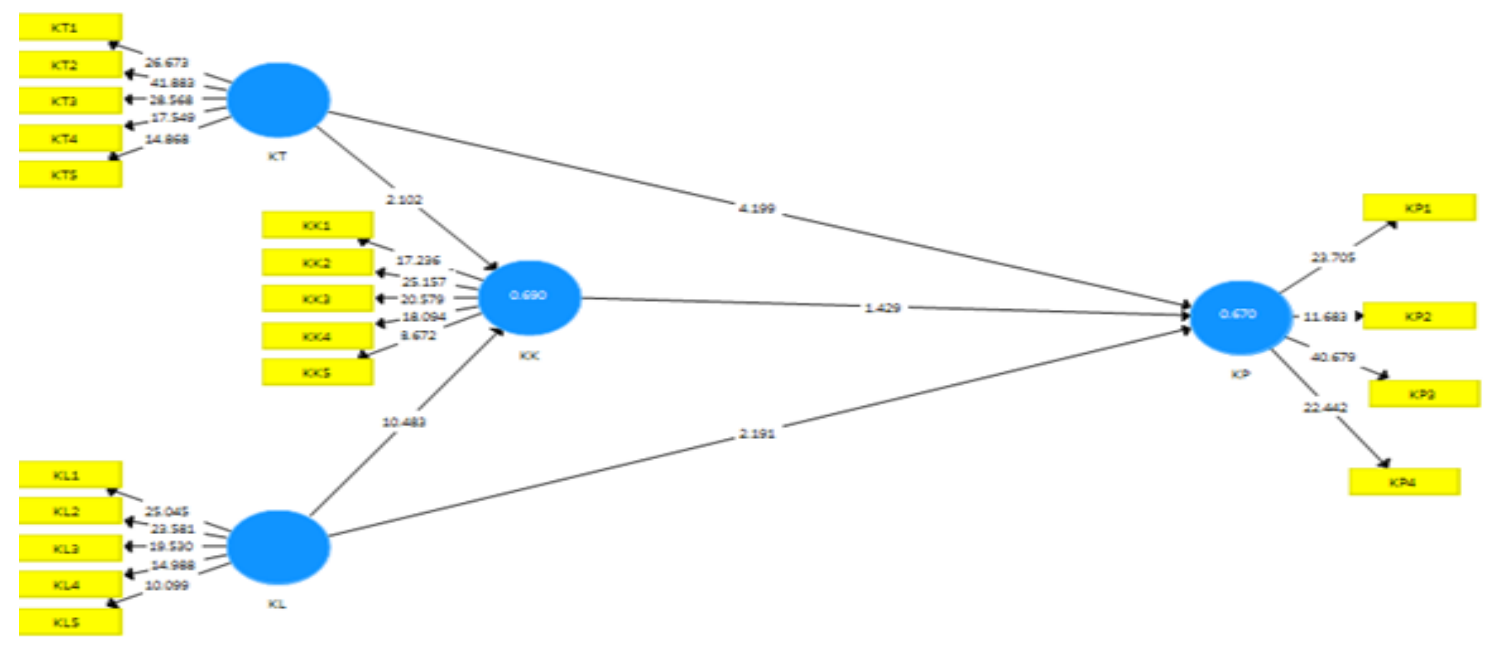

Table 4. 9

Direct Effect

Path Coefficients 


\begin{tabular}{|l|c|c|c|c|c|}
\hline & $\begin{array}{l}\text { Original } \\
\text { Sample (O) }\end{array}$ & $\begin{array}{l}\text { Sample } \\
\text { Mean (M) }\end{array}$ & $\begin{array}{c}\text { Standard } \\
\text { Deviation }\end{array}$ & $\begin{array}{c}\text { t- Statistics ( I } \\
\text { O / STERR / ) }\end{array}$ & P Values \\
\hline KK> KP & 0.199 & 0.195 & 0.140 & 1,429 & 0.154 \\
\hline KL> KK & 0,700 & 0.701 & 0.067 & 10,483 & 0,000 \\
\hline KL> KP & 0.289 & 0.286 & 0.132 & 2,191 & 0,000 \\
\hline KT> KK & 0.181 & 0.183 & 0.086 & 2,102 & 0,000 \\
\hline KT> KP & 0.425 & 0.435 & 0.101 & 4,199 & 0,000 \\
\hline
\end{tabular}

Source : Smart PLS Data Management Results , 2021

Table 4.9 shows that the SmartPLS data management has an impact on the direct influence between variables. Can be said to have direct effect if the t- statistic $>1,96$ and can be said to have no effect if the t-statistic $<1.96$. Based on table 4.9 it has that result. Variable customer satisfaction does not affect the variable purchasing decision with a t-statistic $1.429<1,96$. The service quality variable has an effect on the customer satisfaction variable with a tstatistic of $10.483>1,96$. The service quality variable has an effect on the purchasing decision variable with a t-statistic of 2.191>1,96. The ease of transaction variable has an effect on the customer satisfaction variable with a t-statistic of $2.102<1,96$. Variable ease of transaction affects the variable purchasing decision with a t-statistic 4.199>1,96 .

\section{CONCLUSION}

In this study it can be concluded that the service quality influence on customer satisfaction which has an understanding if the increase in the service quality will increase customer satisfaction, ease of transaction effect on customer satisfaction which means that if an increase in the ease of the transaction will increase customer satisfaction, the ease of Transactions and service quality together have a significant effect.

on customer satisfaction, service quality has an effect on customer satisfaction, which means that if an increase in service quality will increase purchasing decisions, ease of transactions will affect customer satisfaction, which means that if an increase in ease of transaction will be increase purchasing decision, ease of transaction and service quality together have a significant effect on purchasing decision, and customer satisfaction has no effect on purchasing decision, which means that if there is an increase in customer satisfaction, it does not mean that it will cause an increase in purchasing decisions.

\section{REFERENCES}

Celik \& Y1lmaz . 2011. “ Extending the Model Acceptance of Technology for Adoption of E-shopping to customer in Turkey ". Electronic Commerce Research Journal, Vol 12 No. 2 
Damayanti and Wahyono. 2015. " The Influence of Product Quality, Brand Image for Loyality with Satisfaction as an Intervening Variabel". Journal of Management Analysis 4 (3).

Ghozali , I \& Latan , H. 2015. Concepts, Techniques, Application using Smart PLS 3.0 for Empirical research. BP Undip Semarang.

Iskandar, Saparso and Wahyoedi. 2020. "Effect of Service Quality and Price Perception Of Loyalty The Mediated By Satisfaction Customer ." Journal of Managem ent Science and Accounting Vol. 8, No.1, 2020. Pages 18-25.

Irawan , H .2009 . Ten Principles Satisfaction Customer . Jakarta. Elex Media Komputind o.

Kotler, Philip and Kevin L. 2016. Marketing Management International Edition $15^{\text {th }}$. Pearson Education

Kotler, Philip \& Armstrong G. 2018. Principles of Marketing. Pearson Higher Education. International 17 th Edition. New Jersey.

Mantauv . 2014. " Effect Image Brand and Quality Products Against Decision Purchase Toyota Rush With Variabel Intervening Satisfaction Consumers". eJournal of Economics and Vol 2 No 2,81-88.

Miramadi, Sayed Abbas and Nawaser, Khaled . 2011. Study Effect of Service Customers and Quality Products to Satisfaction and Loyality Customer. Journal of Social Sciences and Humanities, (Online), Vol.1 No.7

Pardede and Haryadi . 2017. "Influence Perception of Price and Quality Products to Purchase Decision That Are Mediated by Customers Satisfaction. Journal Of Businees \& Applied Management Vol.10 No.1

Prasetio . 2012. " Effect of Quality of Service and Price Of Satisfaction Customer". Journal of Management Analysis 1 (2).

Rico, M Tecoalu , S Wahyoedi , ED Purnama ( 2019) “The Effect Trust, Service Quality and Perceived Value on Satisfaction and Their Impact on Loyality" International Conference on Entrepreneurship and Business Management (ICEBM Untar 2018), pages 325-330.

Riza and Sutopo.2017. "Analysis of Effect of Quality of e-services, Quality of Information and Perceived Ease of Loyality with e-satisfaction as an Intervening Variabel.( Study On Customer Lazada Indonesia)." Diponegoro University Managem ent Journal . Vol 6 No 4, ISSN ( Online ): 2337-3792.

Rohmatin and Andjarwati. 2019. "The Effect of Service Quality and Ease of Use Repuchase Intentions with Satisfaction as a Mediation Variabel". Management Science Vol 7 No. 1. Faculity of Economics. Surabaya University.

Schiffman , LG, and Kanuk .2010. Consumer Behavior (10th ed .). New Jersey.

Sugiyono . 2018. Methods Research Quantitative, Kualitatif and R \& D. Bandung : Alphabet. 
Sumarwan . 2011. Consumer Behavior Theory and Its Implementaion in Marketing. PT Ghalia Indonesia, Jakarta.

Supranto. 2011 . Measurement Level of Satisfaction Customers, Rineka Notices. Jakarta Swastha, Bayu. 2008. Modern Marketing Management. Yogyakarta : Liberty.

Wijaya and Kempa. 2018. "Effect of Trust, Ease, Quality Information to Satisfaction Consumers Through Decision Purchases Products Fashion in Lazada." AGORA Journal Vol. 6 No. 2

Yuen \& Thai, 2015. International Journal of Quality and Service Sciene, "Service Quality and customer satisfaction in linner shipping".

Yulianto , Arief . 2010. Improving kualiatas service flights Indonesia after the incident an accident aircraft fly. Journal of Management Dynamics Vol. 1 (1). Pp 1-8

\section{Website}

https://www.apjii.co.id

https://www.topbrand-award.com/

www.Mediakonsumen.com

www.dailysocial.co.id

www.Mediakonsumen.com 